\title{
Aplikasi Penerimaan Siswa Baru Studi Kasus Sdi Oebufu Kupang Menggunakan $\mathrm{Vb} 6.0$
}

\author{
Eufemia Eleonora Noo \\ Program Studi Ilmu Komputer, Fakultas Teknik, Universitas Katolik Widya Mandira Kupang Jln. Jendral \\ Achmad Yani No. 50-52 Kupang- NTT,_telp. 0380-833395 \\ e-mail: Eufemiaeleonora20@gmail.com
}

\begin{abstract}
Abstrak
Penerapan aplikasi penerimaan siswa baru adalah sebuah aplikasi komputer yang dibangun untuk memberikan kemudahan dalam penerimaan siswa baru yang pencatatan dan pendataannya menggunakan sebuah aplikasi khusus yang dianggap penulis lebih efektif. Aplikasi tersebut diatas dapat memberikan manfaat bagi pengguna maupun lembaga sekolah dengan menyediakan banyak informasi berupa laporan-laporan dari system yang secara garis besar berupa laporan data calon siswa baru dan laporan pemasukan keuangan pendaftaran siswa. Selain itu pengguna dapat melakukan pengaksesan data dengan mudah dan cepat sehingga tidak memerlukan waktu yang lama dan dapat meringankan beban serta meningkatkan kinerja kerja dari panitia penerimaan siswa baru. Metode penelitian yang digunakan pada aplikasi ini adalah metode waterfall .

Dari permasalahan diatas dapat disimpulkan bahwa dengan adanya "Aplikasi Penerimaan Siswa Baru Dengan Menggunakan Visual Basic 6.0 (Studi Kasus SDI Oebufu Kupang)" dapat membantu memperlancar tugas dari pihak pengolahan data siswa dalam mendata dan menyajikan informasi yang lengkap dan terupdate setiap saat, serta lebih menjamin kualitas penyimpanan dan pengolahan data dibandingkan dengan penyimpanan dan pengolahan data pada sistem yang lama.
\end{abstract}

Kata Kunci : Aplikasi, Penerimaan siswa baru, Visual Basic 6.0

\begin{abstract}
The application of new student admissions applications is a computer application that was built to provide convenience in admitting new students whose recording and data collection uses a special application that the author considers more effective. The application mentioned above can provide benefits to users and school institutions by providing a lot of information in the form of reports from the system which are broadly in the form of data reports on prospective new students and student registration financial income reports. In addition, users can access data easily and quickly so that it does not require a long time and can lighten the burden and improve the work performance of the new student admissions committee. The research method used in this application is the waterfall method. From the above problems it can be concluded that the existence of "Application for New Student Admission Using Visual Basic 6.0 (Case Study of SDI Oebufu Kupang)" can help facilitate the task of processing student data in recording and presenting complete and updated information at any time, as well as ensuring more assurance. the quality of data storage and processing compared to data storage and processing on the old system.
\end{abstract}

Key Words: Application. New student Admission. Visual Basic 6.0 


\section{PENDAHULUAN}

Perkembangan teknologi dalam era globalisasi saat ini melaju dengan sangat pesat dan informasi yang beredar semakin banyak dan kompleks sehingga dunia pendidikan harus dapat mengikuti perkembangan teknologi terutama dalam bidang teknologi komputer. [1]

Penerimaan siswa baru merupakan salah satu proses yang ada di instansi pendidikan seperti sekolah yang berguna untuk menyaring calon siswa yang terpilih sesuai kriteria yang ditentukan oleh sekolah tersebut untuk menjadi siswa didiknya. Pada umumnya proses penerimaan siswa baru dilakukan melalui tahapan pendaftaran, tes seleksi, dan pengumuman penerimaan siswa. [2]

SDI Oebufu adalah sekolah dasar yang berada di Jl. Dua Lontar, Kayu Putih, Kec. Oebobo, Kota Kupang. Sebuah sekolah dasar dengan jumlah murid sebanyak 400 siswa dan jumlah guru sebanyak 24 orang ini didirikan pada tanggal 14 April 1983. Namun ada permasalahan yang saat ini ada pada SDI Oebufu yaitu proses penerimaan siswa baru yang dilaksanakan masih secara manual dalam hal ini pendataan dilakukan dengan menggunakan aplikasi bawaan Microsoft (excel dan word) dan juga tidak memiliki database. Proses penerimaan siswa baru yang masih manual tidak terlalu efektif, sehingga seringkali terjadi kesalahan atau kehilangan data karena belum memiliki database dan juga agar lebih mempermudah kinerja dari operator sekolah dalam mengolah data-data siswa baru.

Solusi yang ingin diterapkan untuk menyelesaikan permasalahan diatas adalah dengan membangun sebuah sistem yang berjudul "Aplikasi Penerimaan Siswa Baru Studi Kasus Sdi Oebufu Kupang" yang menangani secara khusus terhadap proses penerimaan siswa baru pada SDI Oebufu Kupang, sehingga dapat memberikan kemudahan, kecepatan,dan ketepatan serta dapat meminimalisir terjadinya kesalahan dalam pengolahan data pada proses penerimaan siswa baru dan pembuatan laporan kepada pimpinan.

\section{METODE PENELITIAN}

Adapun metode pengembangan perangkat lunak menggunakan metode pengembangan waterfall model. Dalam waterfall terdapat beberapa tahapan utama yang menggambarkan aktivitas pengembangan perangkat lunak. Alasan menggunakan metode waterfall karena tahaptahap dalam pengembangan sistem pada model waterfall terstruktur secara jelas.[3]

Kelima tahapan tersebut seperti pada gambar dibawah ini :

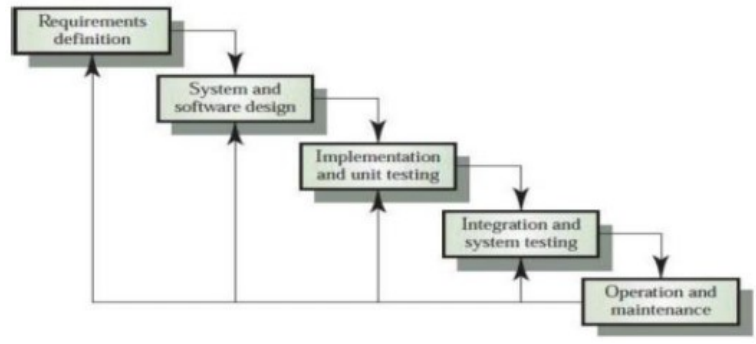

Gambar 1. Model Waterfall

Berikut ini penjabaran tahapan-tahapan waterfall:

\subsection{Tahap Requirement Definition}

Merupakan tahapan penetapan fitur, kendala dan tujuan sistem melalui wawancara dengan pengguna sistem. Semua hal tersebut akan ditetapkan secara rinci dan berfungsi sebagai spesifikasi sistem yang diperlukan dalam pembuatan aplikasi pengolahan data untuk penerimaan siswa baru. Kegiatan yang dilakukan pada tahap ini adalah menganalisis sistem yang sedang berjalan yaitu pengolahan data- data penerimaan siswa baru yang masih bersifat manual, lalu 
data tersebut diketik dalam microsoft (excel dan word) dan masih belum memiliki database untuk penyimpanan datanya.

\subsection{Tahap System and Software Design}

Dalam tahap ini akan dibentuk suatu arsitektur sistem berdasarkan persyaratan yang telah ditetapkan; mengidentifikasi dan menggambarkan abstraksi dasar sistem perangkat lunak; serta menggambarkan hubungan-hubungannya. Proses desain merupakan syarat kebutuhan sebuah perancangan perangkat lunak yang dapat diperkirakan sebelum membuat koding. Pada tahap ini, langkah-langkah yang harus dilakukan adalah memiliki perangkat yang akan digunakan untuk membangun sistem. Perangkat tersebut adalah perangkat keras (hardware) berupa komputer, perangkat lunak (software) berupa program dan perangkat manusia (brainware).

\subsection{Tahap Implementation and Unit Testing}

Pada tahap ini, hasil dari desain perangkat lunak akan direalisasikan sebagai satu set program atau unit program. Setiap unit akan diuji apakah sudah memenuhi spesifikasinya ataukah belum. Untuk dapat dimengerti oleh mesin, dalam hal ini adalah komputer, maka proses desain harus diubah bentuknya menjadi bentuk yang dapat dimengerti oleh mesin, yaitu ke dalam bahasa pemrograman melalui proses coding. Tahap ini merupakan implementasi dari tahap desain yang secara teknis nantinya dikerjakan oleh programmer. Dalam pembuatan program ini akan dirancang dengan menggunakan bahasa pemrograman Visual Basic 6.0 dan Database Microsoft Access 2007.

\subsection{Tahap Integration and System Testing}

Pada tahap ini, setiap unit program akan diintegrasikan satu sama lain dan diuji sebagai satu sistem yang utuh untuk memastikan apakah sistem sudah memenuhi persyaratan ataukah belum. Setelah itu sistem akan dikirim ke pengguna sistem.

\subsection{Tahap Operation and Maintenance}

Pada tahap ini, sistem diinstal dan mulai digunakan. Selain itu juga memperbaiki error yang tidak ditemukan pada tahap pembuatan. Dalam tahap ini juga dilakukan pengembangan sistem seperti penambahan fitur dan fungsi baru. Pengembangan diperlukan ketika adanya perubahan dari eksternal perusahaan atau lembaga seperti ketika ada pergantian sistem operasi atau perangkat lain.

\section{HASIL DAN PEMBAHASAN}

\subsection{Flowchart Sistem}

Flowchart merupakan bagan alir kerja sistem secara keseluruhan. 


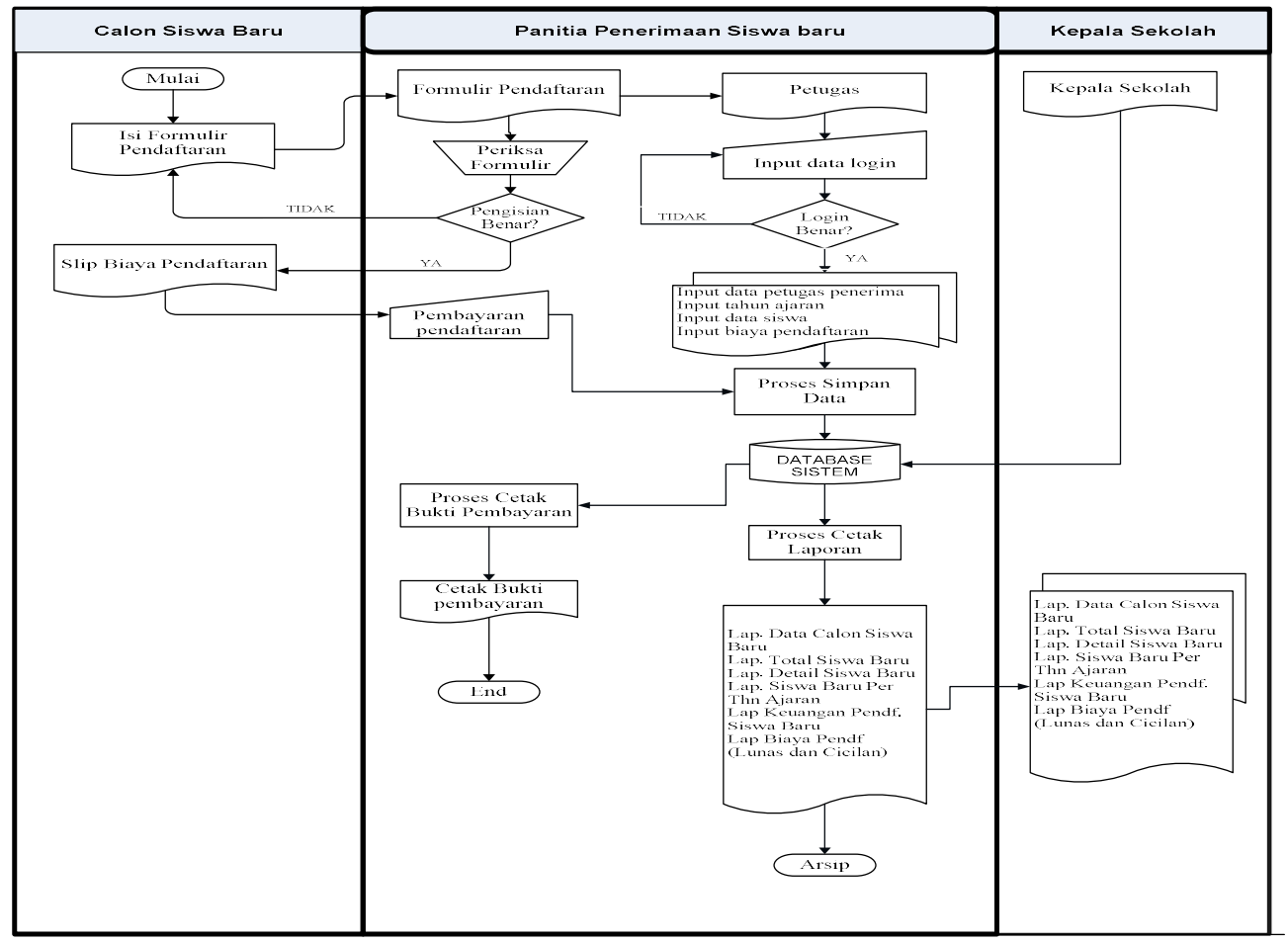

Gambar 2. Flowchart Sistem

\subsection{Data Flow Diagram}

Data Flow Diagram (DFD) adalah suatu model logika data atau proses yang dibuat untuk menggambarkan dari mana asal data dan kemana tujuan data yang keluar dari sistem.

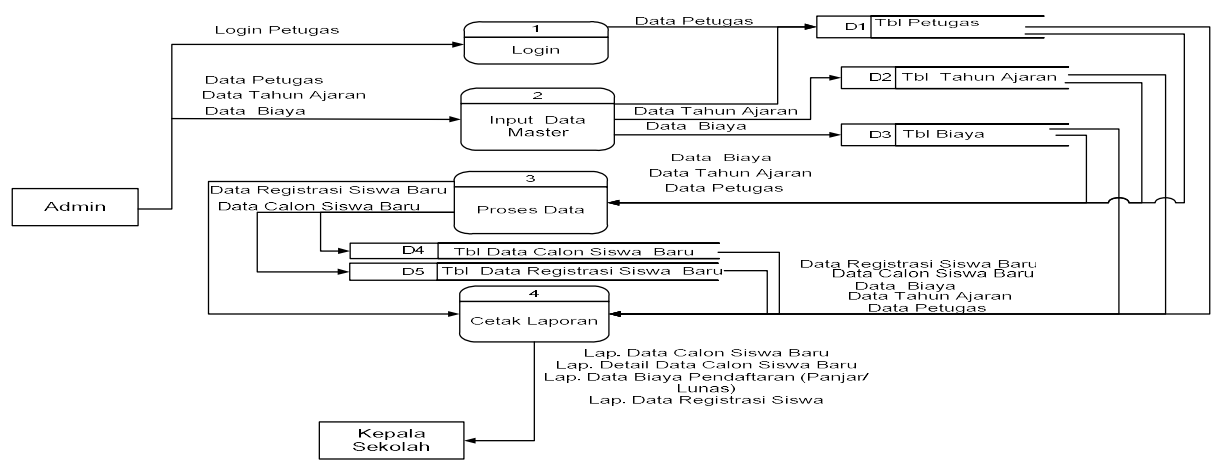

Gambar 3. Data Flow Diagram

\subsection{Entity Relationship Diagram}

ERD merupakan salah satu model yang digunakan untuk mendesain database dengan tujuan menggambarkan data yang berelasi pada sebuah database. 


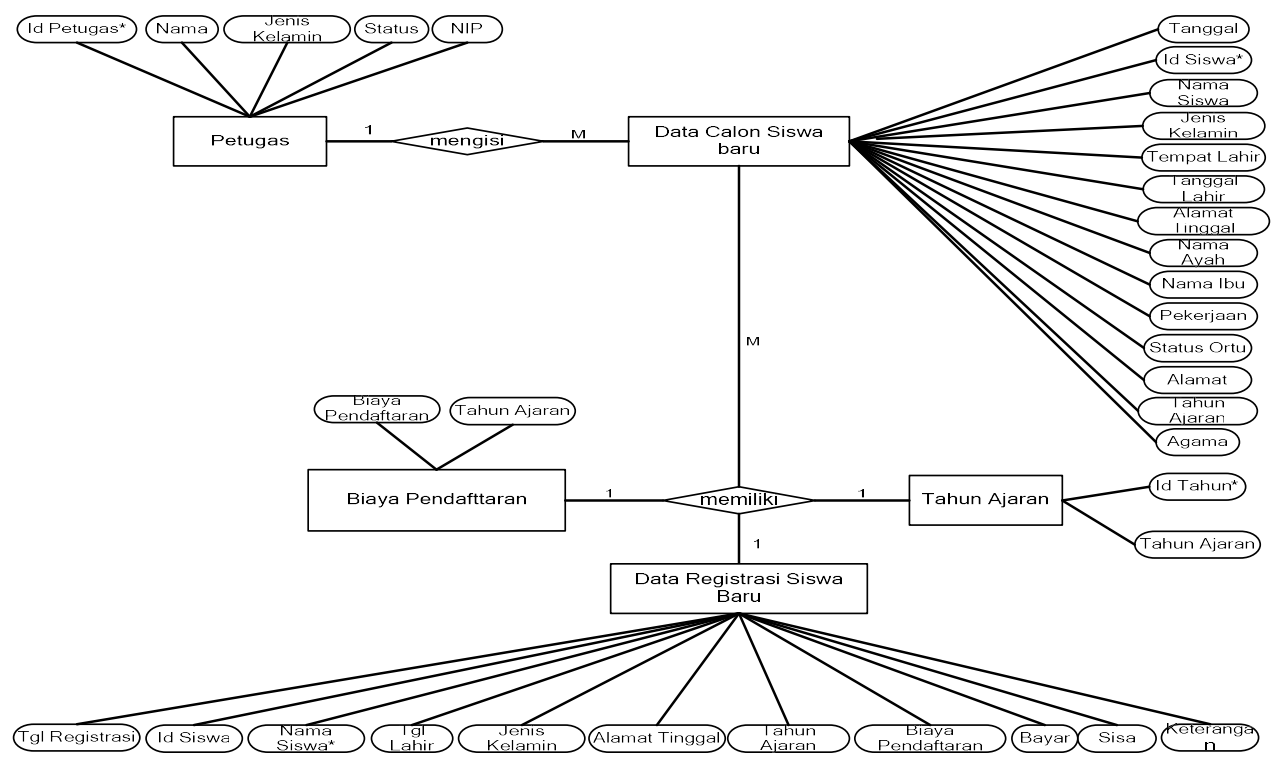

Gambar 4. Entity Relationship Diagram

\subsection{Implementasi Sistem}

Pada tahap ini system akan dibangun dengan bahasa pemrograman visual basic 6.0, dan dihubungkan dengan microsoft access 2007 sebagai database dengan interface sistem berbasis dekstop. Tampilan halaman awal sistem ketika pertama kali kita membuka aplikasi penerimaan siswa baru sebagai berikut :

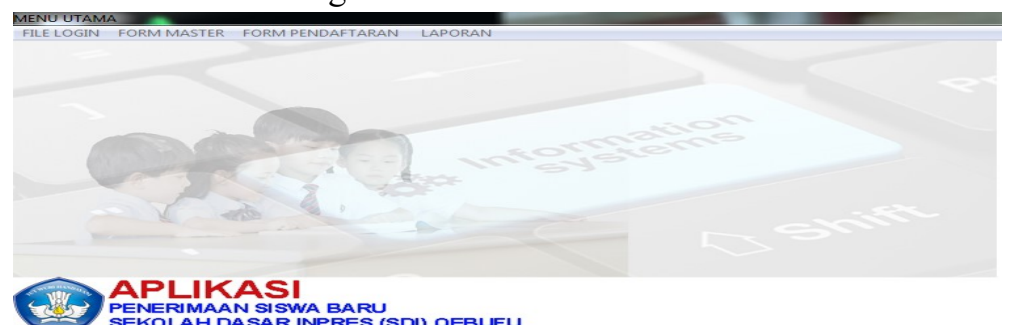

Gambar 5. Tampilan Halaman Utama

Setelah admin membuka tampilan awal sistem maka kini admin diarahkan pada tampilan menu login untuk memasukan username dan password agar admin dapat masuk kedalam sistem.

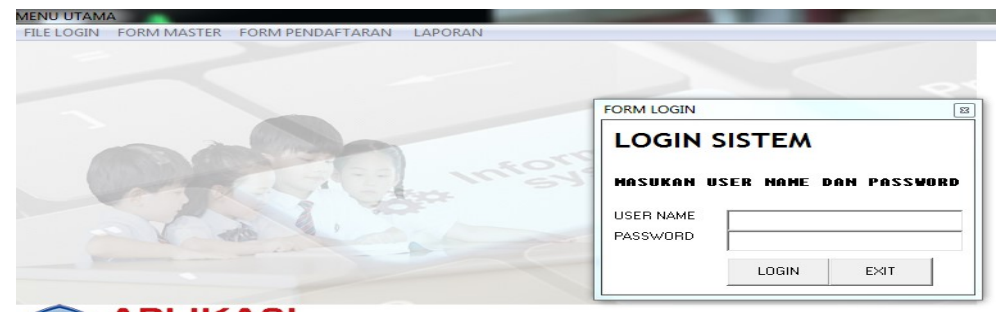

APLIKASI

SEKOLAHDASAR INPRES (SDI) OEBUFU

Gambar 6. Tampilan Menu Login 
Setelah proses login berhasil admin dapat langsung mengisi data petugas, data siswa, data registrasi siswa, data biaya pendaftaran, dan data tahun ajaran. Berikut ini tampilan data petugas:

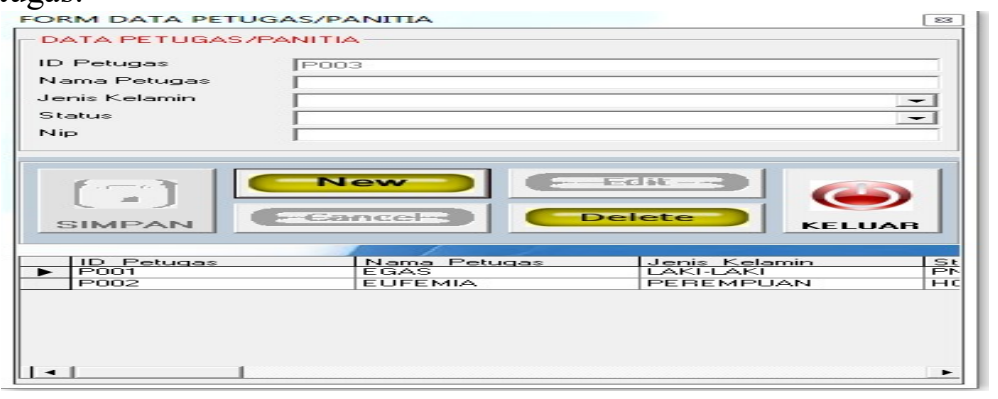

Gambar 7. Tampilan Data Petugas

Pada tampilan tahun ajaran admin dapat mengisi id tahun, dan tahun ajaran.

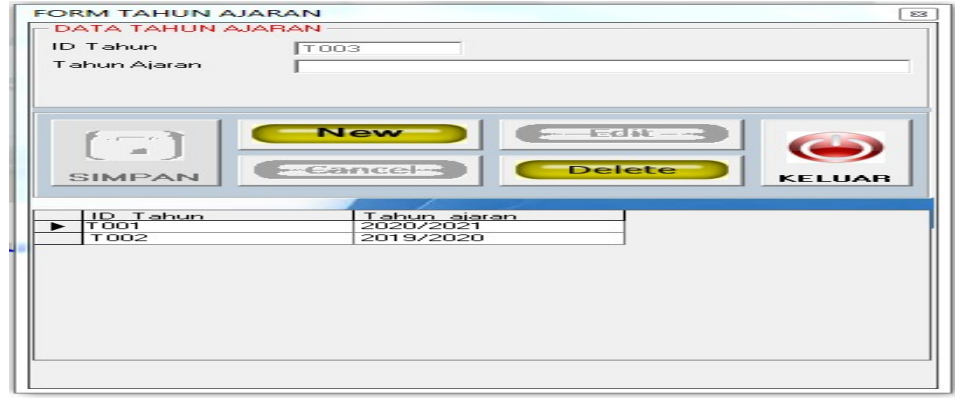

Gambar 8. Tampilan Tahun Ajaran

Pada tampilan biaya pendaftaran admin mengisi tahun ajaran dan biaya pendaftaran sebagai berikut:

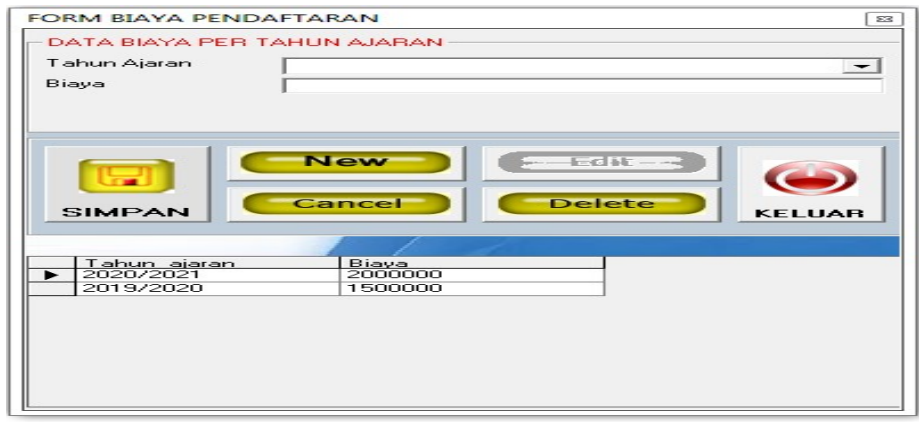

Gambar 9. Tampilan Biaya Pendaftaran

Pada tahap ini admin mengisi data-data calon siswa berupa tanggal pendaftaran, id siswa, nama siswa, jenis kelamin, tempat dan tanggal lahir, alamat tinggal, agama, nama ayah, nama ibu, pekerjaan ayah, pekerjaan ibu, status orang tua/wali, dan alamat tinggal orang tua.Berikut tampilan data calon siswa: 


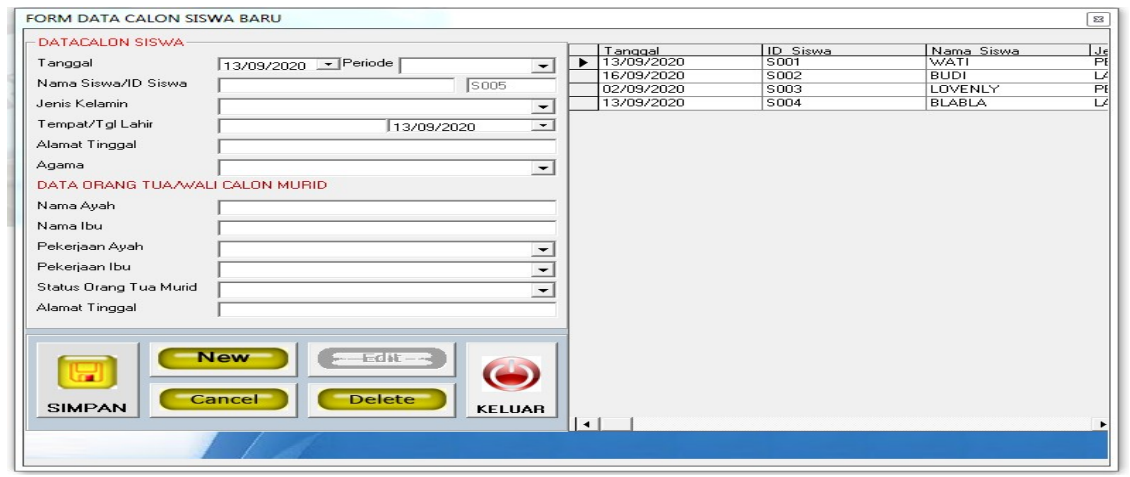

Gambar 10. Tampilan Data Calon Siswa

Pada tampilan registrasi siswa ini admin mengisi tanggal registrasi, tahun ajaran, nama siswa, id siswa, jenis kelamin, tempat dan tanggal lahir, alamat tinggal, biaya pendaftaran, bayar, sisa pembayaran, dan keterangan pembayaran. Berikut tampilan data registrasi siswa:

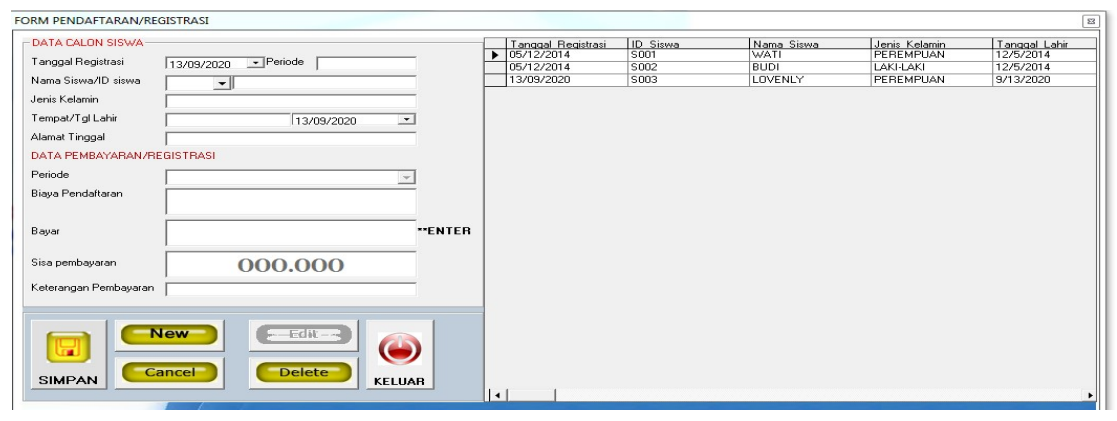

Gambar 11. Tampilan Registrasi Siswa

Berikut tampilan laporan biaya pendaftaran:

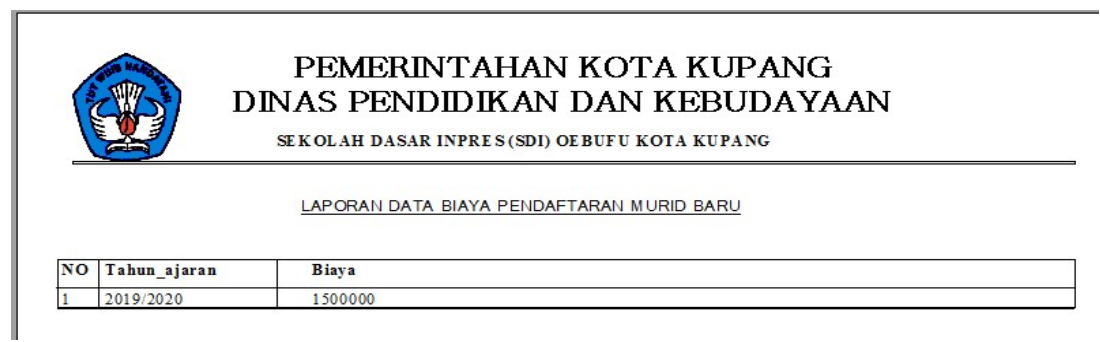

Gambar 12. Tampilan Laporan Biaya Pendaftaran

Berikut ini tampilan laporan data calon siswa baru:

PEMERINTAHAN KOTA KUPANG

DINAS PENDIDIKAN DAN KEBUDAYAAN

SE KOLAH DASAR INPRES (SDI) OEBUFU KOTA KLPANG

LAPORAN DATA MURID BARU PER PERIODE

\begin{tabular}{|c|c|c|c|c|c|c|c|c|}
\hline No Tanng al & D_Sisval Numa_iswa & Fenis_Kel & Tempat_Lathir & Tangzal_Lahit & Alamat_Tinggal & Nema_Aygh & Nama_Lbu & Fatats__oratz_Tat \\
\hline $\begin{array}{ll}1 & 090222020 \\
\end{array}$ & 5003 LOVENLY & EEREMPUAI & KUPANG & 0913222020 & AL $A K$ & EVOGIUS & RosALIIA & ORANG TUA KAND \\
\hline
\end{tabular}

Gambar 13. Tampilan Laporan Data Calon Siswa 
Tampilan laporan detail siswa dapat dilihat pada gambar berikut:

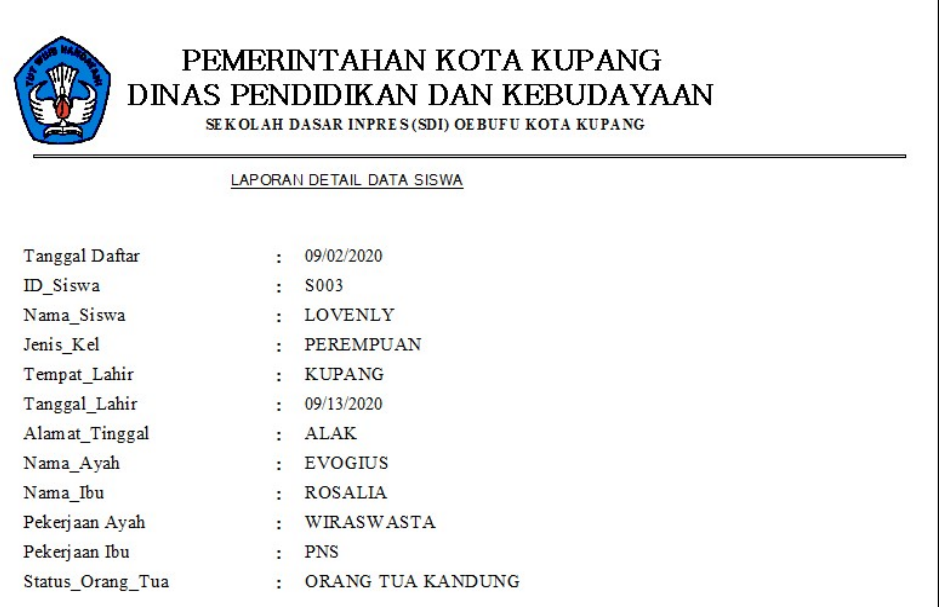

Gambar 14. Tampilan laporan detail data siswa

Tampilan laporan data registrasi siswa dapat dilihat pada gambar berikut:

\begin{tabular}{|c|c|c|c|c|c|c|c|}
\hline D. & $\begin{array}{r}\text { PEN } \\
\text { INAS I } \\
\text { SEKO }\end{array}$ & $\begin{array}{l}\text { ERINT } \\
\text { ENDIDI } \\
\text { AH DASAR II }\end{array}$ & $\begin{array}{l}\text { KOTA K } \\
\text { DAN KE } \\
\text { ) ВEUU KOI }\end{array}$ & $\begin{array}{l}\text { UPANG } \\
\text { BUDAYAA } \\
\text { KUPANG }\end{array}$ & & & \\
\hline & & PORAN DATA & RU PER PERIOI & & & & \\
\hline No Tanggal_Registrasi & $\mathbb{D}_{\text {_ Siswa }}$ & Nama_Siswa & Jenis_Kelamin & Biaya_Pendaftaran & & & Keterang an \\
\hline $10551220140000: 00$ & 5001 & WATI & $\begin{array}{l}\text { PEREMPUAN } \\
\end{array}$ & Rp 2.000.000 & $\operatorname{Rp} 1.000 .000$ & Rp 1.000.000 & PANJAR \\
\hline 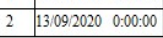 & 5003 & LOVENLY & $\begin{array}{l}\text { PEREMPUAN } \\
\end{array}$ & $\operatorname{Rp} 2.000 .000$ & Rp 500.000 & $\operatorname{Rp} 1.500 .000$ & PANJAR \\
\hline
\end{tabular}

\subsection{Pengujian}

Gambar 15. Tampilan laporan data registrasi siswa

Metode pengujian yang digunakan dalam penelitian ini adalah black box testing. Pengujian black box testing merupakan sebuah metode yang digunakan untuk menemukan kesalahan dan mendemonstrasikan fungsional aplikasi saat dioperasikan, apakah input diterima dengan benar dan output yang dihasilkan telah sesuai dengan yang diharapkan atau belum. Contohnya jika ada software yang menampilkan form input data petugas, jika admin melengkapi form maka program akan melakukan proses simpan, namun jika admin tidak melengkapi form program, maka tidak bisa melakukan proses simpan, jika perangkat lunak tidak sesuai misalnya tidak melengkapi form namun dapat tersimpan, hal ini perlu untuk diperbaiki.

\begin{tabular}{|c|c|c|c|c|c|}
\hline No & Deskripsi & Input & $\begin{array}{l}\text { Hasil Yang } \\
\text { Diharapan }\end{array}$ & Output & Kesimpulan \\
\hline \multirow[t]{2}{*}{1} & \multirow{2}{*}{$\begin{array}{l}\text { Login } \\
\text { Admin }\end{array}$} & \multirow{2}{*}{$\begin{array}{l}\text { Masukan } \\
\text { password atau } \\
\text { username } \\
\text { salah }\end{array}$} & \multirow{2}{*}{$\begin{array}{lr}\text { Muncul } & \text { pesan } \\
\text { menyatakan } & \\
\text { username } & \text { atau } \\
\text { password } & \text { salah } \\
\text { silahkan dicoba lagi }\end{array}$} & 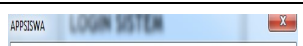 & \multirow{3}{*}{ Sukses } \\
\hline & & & & 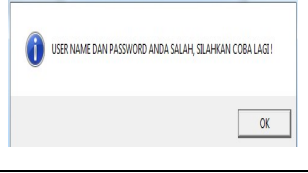 & \\
\hline \multirow[t]{3}{*}{2} & Login & Masukan & Muncul pesan & APPSISWA & \\
\hline & & & & (i) LaGIN BerHASIL & 107 \\
\hline & & & & оK & \\
\hline
\end{tabular}




\begin{tabular}{|c|c|c|c|c|c|}
\hline & Admin & $\begin{array}{l}\text { password dan } \\
\text { username } \\
\text { benar }\end{array}$ & $\begin{array}{l}\text { menyatakan login } \\
\text { berhasil }\end{array}$ & & Sukses \\
\hline 3 & $\begin{array}{l}\text { Menambah } \\
\text { data } \\
\text { petugas }\end{array}$ & $\begin{array}{l}\text { Menambah } \\
\text { data petugas }\end{array}$ & $\begin{array}{l}\text { Muncul pesan data } \\
\text { tersimpan }\end{array}$ & 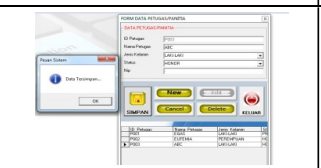 & Sukses \\
\hline 4 & $\begin{array}{l}\text { Menambah } \\
\text { data tahun } \\
\text { ajaran }\end{array}$ & $\begin{array}{l}\text { Masukan kode } \\
\text { tahun dan } \\
\text { tahun ajaran }\end{array}$ & $\begin{array}{l}\text { Muncul pesan data } \\
\text { tersimpan }\end{array}$ & 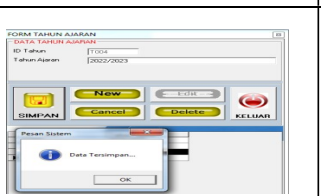 & Sukses \\
\hline 5 & $\begin{array}{l}\text { Menambah } \\
\text { data biaya }\end{array}$ & $\begin{array}{l}\text { Masukan } \\
\text { tahun ajaran } \\
\text { dan biaya }\end{array}$ & $\begin{array}{l}\text { Muncul pesan data } \\
\text { tersimpan }\end{array}$ & 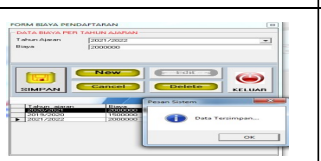 & Sukses \\
\hline 6 & $\begin{array}{l}\text { Menambah } \\
\text { data calon } \\
\text { siswa baru }\end{array}$ & $\begin{array}{l}\text { Input data } \\
\text { siswa baru dan } \\
\text { data orang tua } \\
\text { siswa }\end{array}$ & $\begin{array}{l}\text { Muncul pesan data } \\
\text { tersimpan }\end{array}$ & 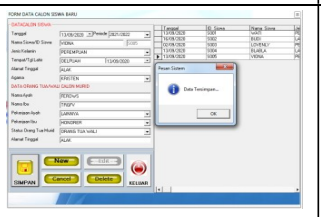 & Sukses \\
\hline 7 & $\begin{array}{l}\text { Menambah } \\
\text { data } \\
\text { registrasi } \\
\text { siswa baru }\end{array}$ & $\begin{array}{lr}\text { Input } & \text { tanggal } \\
\text { dan } & \text { tahun } \\
\text { ajaran. } & \\
\end{array}$ & $\begin{array}{l}\text { Muncul pesan data } \\
\text { tersimpan }\end{array}$ & 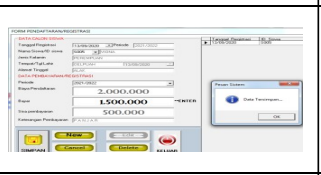 & Sukses \\
\hline 8 & $\begin{array}{l}\text { Mencetak } \\
\text { laporan } \\
\text { biaya } \\
\text { pendaftaran }\end{array}$ & $\begin{array}{l}\text { Input tahun } \\
\text { ajaran lalu klik } \\
\text { cetak }\end{array}$ & $\begin{array}{l}\text { Masuk ke halaman } \\
\text { cetak laporan }\end{array}$ & 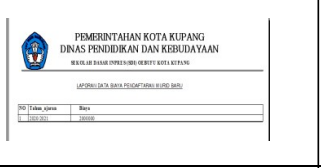 & Sukses \\
\hline 9 & $\begin{array}{l}\text { Mencetak } \\
\text { laporan } \\
\text { data calon } \\
\text { siswa baru }\end{array}$ & $\begin{array}{l}\text { Masukan } \\
\text { tahun ajaran } \\
\text { lalu cetak }\end{array}$ & $\begin{array}{l}\text { Masuk ke halaman } \\
\text { cetak laporan }\end{array}$ & 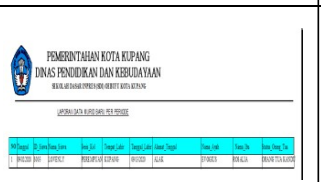 & Sukses \\
\hline 10 & $\begin{array}{l}\text { Cetak } \\
\text { laporan } \\
\text { detail data } \\
\text { calon siswa }\end{array}$ & $\begin{array}{lr}\text { Masukan } & \text { id } \\
\text { dan } & \text { nama } \\
\text { siswa } & \text { lalu } \\
\text { cetak } & \\
\end{array}$ & $\begin{array}{l}\text { Masuk ke halaman } \\
\text { cetak laporan }\end{array}$ & 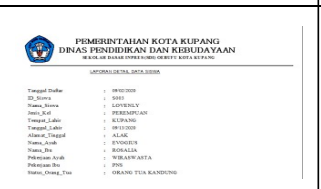 & Sukses \\
\hline 11 & $\begin{array}{l}\text { Cetak } \\
\text { laporan } \\
\text { data } \\
\text { registrasi } \\
\text { siswa baru }\end{array}$ & $\begin{array}{l}\text { Masukan } \\
\text { tahun ajaran } \\
\text { lalu cetak }\end{array}$ & $\begin{array}{l}\text { Masuk ke halaman } \\
\text { cetak laporan }\end{array}$ & 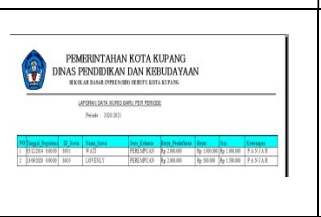 & Sukses \\
\hline
\end{tabular}

\subsection{Pembahasan}

Dari hasil pengujian menggunakan metode black box terhadap sistem dapat dilihat bahwa secara umum sistem mampu menjalankan proses login, tambah data, cetak data, melihat laporan.

Untuk dapat mengakses aplikasi admin wajib melakukan login. Saat login harus memperhatikan username dan password, jika salah memasukkan username dan password 
maka akan muncul pesan bahwa username atau password yang dimasukkan salah. Jika username dan password sesuai maka admin akan masuk kehalaman utama dan bisa menambahkan data petugas, data siswa baru, data tahun ajaran, data biaya pendaftaran, dan data registrasi siswa baru. Untuk bisa mencetak data maka pilih cetak data maka data akan muncul dalam bentuk $p d f$ dan siap dicetak.

\section{KESIMPULAN}

Berdasarkan hasil pembahasan sebelumnya, penulis dapat menyimpulkan bahwa dengan adanya Aplikasi Penerimaan Siswa Baru ini diharapkan:

1. Dapat membantu mempermudah proses penerimaan siswa baru setiap tahun pada SDI Oebufu Kupang. Aplikasi tersebut diatas akan digunakan untuk mendata setiap siswa baru yang bersekolah di SDI Oebufu Kupang sampai pada proses pembayaran biaya pendaftaran baik cicil maupun dibayar lunas oleh calon siswa.

2. Aplikasi juga akan membantu pihak sekolah dalam melakukan perbandingan jumlah calon siswa dengan tahun-tahun sebelumnya karena telah dilengkapi dengan laporan - laporan yang sangat akurat.

3. Dengan adanya Aplikasi Penerimaan Siswa Baru ini juga dapat lebih menjamin kwalitas penyimpanan data yang jauh lebih baik dibandingkan dengan sistem penyimpanan data yang diterapkan sebelumnya dan dapat meningkatkan efektifitas kerja pegawai atau panitia penerimaan calon siswa baru pada SDI Oebufu Kupang.

\section{SARAN}

Adapun saran yang dapat diberikan yaitu disarankan pihak SDI Oebufu Kupang dapat memanfaatkan Aplikasi Penerimaan Siswa Baru ini sebagai bentuk pemanfaatan perkembangan kemajuan teknologi dimana saat ini sudah sebagian besar pekerjaan manusia dialihkan ke komputer, sehingga semua proses pekerjaan dapat berjalan dengan cepat.

[1] K. Anam, “ANALISA DAN PERANCANGAN SISTEM INFORMASI AKADEMIK BERBASIS WEB PADA MI AL-MURSYIDIYYAH AL-

‘ASYIROTUSSYAFI'IYYAH,” J. Tek. Inform., vol. 11, no. 2, pp. 207-217, 2018.

[2] N. Najamudin, W. Bagye, and M. Ashari, "APLIKASI PENERIMAAN PESERTA DIDIK BARU BERBASIS WEB PADA SMK NEGERI 2 KURIPAN," J. Manaj. Inform. dan Sist. Inf., vol. 2, no. 2, p. 17, 2019.

[3] S. Sarwindah, "SISTEM PENDAFTARAN SISWA BARU PADA SMP N 1 KELAPA BERBASIS WEB MENGGUNAKAN MODEL UML," J. Sisfokom (Sistem Inf. dan Komputer), vol. 7, no. 2, p. 110, 2018. 